\title{
Anti-inflammatory and neuroprotective effects of astragalin isolated from Aster scaber
}

\author{
Eun-Hae Kim ${ }^{1}$, Sanghyun Lee ${ }^{2}$, Mi Ja Chung ${ }^{1 *}$ \\ ${ }^{1}$ Department of Food Science and Nutrition, Gwangju University, Gwangju 61743, Korea \\ ${ }^{2}$ Department of Plant Science and Technology, Chung-Ang University, Anseong 17546, Korea
}

\section{참취(Aster scaber)에서 분리한 astragalin의 항염증 및 뇌신경세포 보호 효과}

\author{
김은해 ${ }^{1} \cdot$ 이상현 $^{2} \cdot$ 정미자 ${ }^{1 *}$ \\ ${ }^{1}$ 광주대학교 식품영양학과, ${ }^{2}$ 중앙대학교 식물생명공학과
}

\begin{abstract}
The aim of the present study was to investigate the anti-inflammatory effects of astragalin (Ast) isolated from Aster scaber in lipopolyssacharide (LPS)-stimulated Raw264.7 macrophage cells, and the neuroprotective effect of Ast against nitric oxide-induced neuronal cell death. The ethyl acetate fraction of Aster scaber had the highest 2,2diphenyl-1-picrylhydrazyl (DPPH) radical scavenging activity among the ethanol extracts and the five fractions. Cells were pretreated with Ast isolated from the ethyl acetate fraction of Aster scaber and further cultured for an appropriate time after LPS addition. Ast reduced the concentration of nitric oxide (NO), tumor necrosis factor- $\alpha$ (TNF- $\alpha$ ), and interleukin-6 (IL-6) in the Raw264.7 cells activated by the LPS. These inhibitory effects were attributed to the suppression of the mitogen-activated protein kinase (MAPK) pathways by Ast. Sodium nitroprusside (SNP) was used as the NO donor. Ast increased the survival of human SK-N-SH neuroblastoma cells exposed to toxic conditions due to the excessive production of NO. The effect of Ast was observed in co-cultured cells (SK-N-SH cells and microglia). Treatment of SK-N-SH cells with Ast showed protective effects against SNP-induced NO production in microglia. These results suggest that Ast could act as a potential neuroprotective agent via its anti-inflammatory effects.
\end{abstract}

Keywords : Aster scaber, anti-inflammatory, astragalin, macrophage, neuroprotection

\section{서 론}

체내에서 염증반응은 주로 대식세포(macrophage)와 미세 아교세포(microglia)에 의해서 조절되는데, 미세아교세포는 뇌의 해마에 다량 존재하는 대식세포이고 단핵구(monocyte) 에서 분화되어 중추신경계(central nerve system)에 산재하는 비신경세포이다(Kreutzberg, 1996). 뇌 손상이나 감염 등에 의 해 염증반응을 증가시키는 nitric oxide(NO), cyclooxygenase-2
(COX-2)와 같은 염증 매개체들과, interleukin-1 $\beta(\mathrm{IL}-1 \beta), \mathrm{IL}-6$, tumor necrosis factor- $\alpha(\mathrm{TNF}-\alpha)$ 와 같은 염증성 싸이토카인의 분비량이 증가하여 알츠하이머 질환(Alzheimer's disease), 파킨슨 질환(Parkinson's disease) 등과 같은 퇴행성 신경 질 환의 주요 원인이 되는 것으로 알려져 있다(McGeer과 McGeer, 2004). 염증이 과하게 증가하면 NO 분비량이 증가 하고, $\mathrm{NO}$ 는 peroxynitrite( $\left(\mathrm{ONOO}^{-}\right)$, superoxide anion $\left(\mathrm{O}_{2}{ }^{\circ}\right)$, $\mathrm{H}_{2} \mathrm{O}_{2}$ 등과 같은 활성산소종(reactive oxygen species, $\mathrm{ROS}$ )

*Corresponding author. E-mail : mijachung@gwangju.ac.kr, Phone : +82-62-670-2049, Fax : +82-62-670-2062

Received 21 October 2021; Revised 06 December 2021; Accepted 06 December 2021.

Copyright (c) The Korean Society of Food Preservation.

This is an Open Access article distributed under the terms of the Creative Commons Attribution Non-Commercial License (http://creativecommons.org/licenses/by-nc/4.0) which permits unrestricted non-commercial use, distribution, and reproduction in any medium, provided the original work is properly cited. 
을 생성하여 체내 산화적 스트레스(oxidative stress)를 증가 시킨다(McCord, 1974; Ryu 등, 2003). 따라서, 이러한 염증 유발 매개체들과 염증성 싸이토카인의 분비를 조절하는 것이 염증성 질환을 치료할 수 있는 방법으로 제시되고 있다.

참취(Aster scaber)는 우리나라에서 나물로 식용되어 오거 나 약용으로 사용되는 산채류 중의 하나로 함유된 주요 물질 인 astragalin(Ast)과 isoquercitrin이다(Chung 등, 2016).

Astragalin은 대식세포에서 염증반응에 의해 활성화된 $\mathrm{NF}-\mathrm{kB} /$ mitogen-activated protein kinases(MAPKs) 신호전달 경로(signaling pathway)를 억제함으로써 IL-1 $\beta$, IL-6 그리고 $\mathrm{TNF}-\alpha$ 분비량을 감소시켜 항염증 반응이 있다는 것이 이미 보고되었다(Li 등, 2017; Soromou 등, 2012). 그러나 활성화 된 미세아교세포에서 과량 분비되는 NO에 대항하여 참취에 서 분리된 astragalin이 뇌신경세포를 보호할 수 있는지에 관 한 연구는 전무하다.

본 연구에서는 참취에서 분리된 astragalin의 Raw264.7 대 식세포에서 항염증 효과 및 MAPK 신호전달 경로에 관한 기 전 연구를 하였고, 뇌 해마와 같은 미세아교세포와 뇌신경세 포가 공존하는 유사 조건을 만들어 미세아교세포가 염증반응 으로 과량의 $\mathrm{NO}$ 가 분비될 때 astragalin이 뇌신경세포를 보 호할 수 있는지 알아보았다.

\section{재료 및 방법}

\section{참취(Aster scaber)의 에탄올 추출물 및 분획물 제조}

본 연구에 사용한 참취(A.scaber)는 강원도 양양에서 채취 하였고, 세척 및 건조 후 에탄올을 가한 뒤 환류 장치를 이용 하여 추출한 후 Whatman NO.1 filter paper(Whatman International Ltd., Springfield Mill, Kent, UK)로 여과하여 감압 농축기(Büchi Rotovapor R-205, Büchi Labortechnik $\mathrm{AG}$, Switzerland)를 사용하여 농축하였다. 농축된 추출물은 물에 현탁하여 용매 극성 차이에 따라 헥산(hexane), 클로로 포름(chloroform), 에틸아세테이트(ethyl acetate), 부탄올 (butanol) 및 물(aqueous) 분획물 순서로 분획물들을 얻은 후 감압 농축기(Büchi Rotovapor R-205)를 사용하여 분획 용매 를 제거한 후 동결건조기(Clean vac 8, Hanil, Incheon, Korea) 로 동결건조 한 분말은 $-20^{\circ} \mathrm{C}$ 에 보관하였다. 헥산, 클로로포 름, 에틸아세테이트, 부탄올 및 물 분획물의 동결건조 분말을 각각 $\mathrm{HX}, \mathrm{CH}, \mathrm{EA}, \mathrm{BU}$ 및 $\mathrm{AQ}$ 라 하였다. 에탄올 추출물의 동결건조 분말은 $\mathrm{EtOH}$ 라고 하였다.

\section{참취(Aster scaber)의 에탄올 추출물 및 분획물의 DPPH 라디칼 소거활성 측정}

2,2-diphenyl-1-picrylhydrazyl(DPPH; Sigma-Aldrich Co.,
St. Louis, MO, USA) free radical 소거활성은 참취(A. scaber) 추출물 및 분획물들인 $\mathrm{EtOH}, \mathrm{EA}, \mathrm{BU}, \mathrm{AQ}, \mathrm{CH}$ 그리고 $\mathrm{HX}$ 을 $4,8,15,30,60,125,250$ 그리고 $500 \mu \mathrm{g} / \mathrm{mL}$ 농도로 제조 한 후 시료 $(540 \mu \mathrm{L})$ 와 $\mathrm{DPPH}\left(1.5 \times 10^{-4} \mathrm{M}, 360 \mu \mathrm{L}\right)$ 용액을 섞 은 후 $37^{\circ} \mathrm{C}$ 에서 30 분간 반응시켰다. UV-vis spectrophotometer (Model Ultrospec 3000, Pharmacia Biotech, Cambridge, England)로 $517 \mathrm{~nm}$ 에서 흡광도를 측정하였다. $\mathrm{DPPH}$ 라디 칼 소거 활성은 대조구에 대한 시료 첨가구의 흡광도를 비교 하여 [1 - (시료의 흡광도 / 대조구의 흡광도)] × 100 에 의하여 $\%$ 로 나타내었다.

\section{참취(Aster scaber) 에탄올 추출물의 HPLC 분석}

Agilent reverse-phase HLPC system(Agilent 1260 Infinity II Quat Pump, CA, USA; DAD WR detector, CA, USA) 에 $\mathrm{INNO} \mathrm{C}_{18}$ 역상 칼럼 $(25 \mathrm{~cm} \times 4.6 \mathrm{~mm}, 5 \mu \mathrm{m}$; Young Jin Biochrom Co. Ltd., Korea)을 장착하여 분석하였다. $0.5 \%$ acetic acid가 포함된 물과 acetonitrile 용매 조성이 90:10에 서 30분 후 50:50의 용매 조성이 되게 기울기 용리 방법으로 분석하였다. 파장은 $270 \mathrm{~nm}$, 유속은 $1 \mathrm{~mL} / \mathrm{min}$ 그리고 주입 량은 $10 \mu \mathrm{L}$ 이었다.

\section{참취(Aster scaber) 에틸아세테이트 분획물로부터 분리된 astragalin 분리 및 동정}

참취(Aster scaber) 에탄올 추출물 및 그 분획물들의 뇌신 경세포 보호 효과(data not shown) 및 항산화 효과들을 분석한 결과, 가장 우수한 에틸아세테이트 분획물로부터 astragalin을 분리하였다. 즉, EA $13 \mathrm{~g}$ 을 silica gel(200-400 mesh ASTM; Merck, Co., Germany) column에 dichloromethane을 이용하 여 로딩(loading)하였고, dichloromethane $100 \%$ 에서 methanol $100 \%$ 가 되게 조정된 전개 용매를 이용하여 open chromatography로 총 17 개의 소분획물(sub-fractions)을 얻었다. 그 중 에서 sub-fraction 10 을 재칼럼하여 12 개의 소분획물(subfraction)을 분리하였으며, 그 중 sub-fraction 10-10을 박막크 로마토그래피(prep-Thin Layer Chromatography, Merck, Darmstadt, Germany)를 이용하여 분리하였다. Kiesel gel 60 F254(Art. 5715, Merck Co., Darmstadt, Germany) plates(silica gel, $0.25 \mathrm{~mm}$ layer thickness)를 사용하여 분리된 물질들은 $\mathrm{TLC}$ 전개를 통하여 Rf값을 확인하면서 진행하였고, Rf값과 TLC의 패턴이 같은 물질끼리 grouping을 하였다(Lee 등, 2019). Grouping을 하여 얻은 총 3 개의 sub-fraction을 재칼 럼 한 결과 sub-fraction 10-10-2에서 astragalin을 얻었다. 물 질 확인은 $\mathrm{TLC}$ 를 이용하여 확인하였는데 $\mathrm{TLC}$ 의 전개 용매 조성은 dichloromethane $80 \%$, methanol $20 \%$ 를 사용하여 시행 하였다. 화합물의 구조동정은 Bruker AVANCE 500(Bruker, 
Bremen, Germany)를 이용해 측정한 ${ }^{1} \mathrm{H}$-nuclear magnetic resonance(NMR) spectrum과 ${ }^{13} \mathrm{C}-\mathrm{NMR}$ spectrum 분석을 통하 여 하였고, 최종적으로 astragalin(=kaempferol 3-O-glucoside) 으로 동정하였다(Chung 등, 2016).

\section{세포 배양}

마우스 대식세포주 Raw264.7 세포는 한국세포주은행(Seoul, Korea)에서 구입하여 사용하였고, 미세아교세포(microgila, $\mathrm{EOC20)와} \mathrm{신경모세포종} \mathrm{SK-N-SH} \mathrm{세포는} \mathrm{ATCC(American}$ Type Culture Collection, Manassas, VA, USA)에서 구입하 여 사용하였다. Raw264.7 대식세포와 미세아교세포의 성장 배지는 Dulbecco's modified Eagle's medium(DMEM; WelGene Co.)에 $10 \%$ 비활성화 우태아 혈청(fetal bovine serum, FBS; WelGene Co., Daegu, Korea) 및 1\% penicillin and streptomycin(PEST; WelGene Co.) 용액을 더한 것이고, SK-N-SH 세포의 성장배지는 Minimum Essential Medium Eagle(MEM; WelGene Co.)에 10\% FBS 및 1\% PEST를 함 유한 것이다. Raw264.7 세포, 미세아교세포 및 SK-N-SH 세 포에 배양 배지를 더한 후 $5 \% \mathrm{CO}_{2}$ 가 공급되는 배양기 (Thermo Fisher Scientific, Waltham, MA, USA)에서 $37^{\circ} \mathrm{C}$ 조건으로 배양하였다.

\section{세포 생존율 측정}

Raw264.7 대식세포, 미세아교세포(microgila, EOC20) 및 SK-N-SH 세포는 부착된 세포를 떼어 낸 후 24-well plates에 세포수를 $1 \times 10^{5}$ cells/well로 조정하여 깐 후 24시간 동안 배 양하여 2시간 기아 상태를 유지한 후 Raw264.7 대식세포에 서 세포 독성을 알아보기 위해 Ast $0,0.5,1,2.5$ 그리고 $5 \mu$ $\mathrm{g} / \mathrm{mL}$ 24시간 처리하였다. Sodium nitroprusside(SNP; SigmaAldrich Co., St. Louis, MO, USA) 처리농도를 정하기 위해 SK-N-SH 세포에 SNP 0, 0.025, 0.05, 0.1, 0.25, 0.5, 1, 2, 4 그리고 $8 \mathrm{mM}$ 24시간 처리하였다. 미세아교세포는 SNP 1 $\mathrm{mM}$ 을 18 시간 처리하였다. 더하여 SK-N-SH 세포는 Ast 0.5 , $1,2.5$ 그리고 $5 \mu \mathrm{g} / \mathrm{mL}$ 처리한 2시간 후 $1 \mathrm{mM} \mathrm{SNP}$ 를 처리 하여 18 시간 재배양하였다. SK-N-SH 세포와 미세아교세포 혼합시스템에서 SK-N-SH 세포의 세포 생존율을 측정하였 다. 혼합시스템에서의 처리농도는 "신경세포와 미세아교세 포 혼합시스템 구축” 실험방법에 자세히 설명하였다.

세포 생존율은 Kim 등(2018)이 사용한 3-(4,5-dimethythiazol2-yl)-2,5-dipheyl terazolium bromid(MTT) 환원 방법을 이용 하여 측정하였다. 시료 처리가 끝이 난 세포에 FBS가 함유되 어 있지 않은 배지에 MTT 용액 $(5 \mathrm{mg} / \mathrm{mL})$ 을 10 분의 1 을 넣 었다. $50 \mathrm{~mL}$ 가 필요할 경우 $1 \%$ PEST만 든 배지 $45 \mathrm{~mL}$ 와 MTT 용액 $(5 \mathrm{mg} / \mathrm{mL}) 5 \mathrm{~mL}$ 를 섞어 준비하였다. 각 well에
MTT 용액이 든 배지로 교체한 후 다시 $37^{\circ} \mathrm{C}$ 에서 4시간 더 배양하였다. MTT를 환원시켜 생성된 formazon이 배지에 따 라 나가지 않도록 배지를 조심스럽게 제거하고, 남아 있는 배 지를 완전히 제거하기 위해 실온에서 30 분간 방치한 후 $\mathrm{DMSO}$ (Sigma-Aldrich Co.)를 이용하여 시료를 녹였다. UV-vis spectrophotometer(Model Ultrospec 3000)로 $570 \mathrm{~nm}$ 에서 흡광도를 측정하였다. 흡광도 측정 시 공시료는 $\mathrm{DMSO}$ 로 하였고, 세포의 생존율은 아래와 같이 계산하였다.

$$
\text { 세포 생존율 }(\%)=\frac{\text { 시료 처리군의 흡광도 }}{\text { 대조군의 흡광도 }} \times 100
$$

\section{Nitric oxide 측정}

부착된 세포를 떼어 낸 후 성장 배지에 세포수를 $1 \times 10^{5}$ cells/well로 조정하여 24-well plates에 세포를 깐 후 24시간 동안 배양하여 2시간 기아 상태를 유지한 후 Ast $0.5,1,2.5$ 그리고 $5 \mu \mathrm{g} / \mathrm{mL}$ 를 2시간 동안 처리하였다. Raw264.7 대식 세포는 2 시간 후 $0.5 \mu \mathrm{g} / \mathrm{mL}$ 의 LPS를 처리한 후 18 시간 재배 양하였다. 혼합시스템에서의 처리농도는 "신경세포와 미세 아교세포 혼합시스템 구축" 실험방법에 자세히 설명하였다. 세포 배양 상등액과 동량의 Griess 시약( $1 \%$ sulfanilamide in $5 \%$ phosphoric acid and $1 \% \alpha$-naphtylamide in $\mathrm{H}_{2} \mathrm{O}$ )을 넣 어 혼합하고 암실에서 10 분간 반응시킨 후, UV-vis spectrophotometer(Model Ultrospec 3000)로 $540 \mathrm{~nm}$ 에서 흡광도를 측정하였다. $\mathrm{NO}$ 의 농도는 $\mathrm{NaNO}_{2}$ (sodium nitrite)를 농도별 로 희석하여 준비한 시료의 흡광도 값으로 그린 검량선으로 산출하였다(Choi 등, 2008).

\section{Western blotting 분석}

Raw264.7 대식세포를 6-well plates에 세포수를 $1 \times 10^{6}$ cells/well로 조정하여 깐 후 24시간 동안 배양하였다. 시료 처리는 2 시간 기아 상태를 유지한 후 Ast $0.5,1,2.5$ 그리고 $5 \mu \mathrm{g} / \mathrm{mL}$ 를 2시간 동안 처리하였고, 2시간 후 $0.5 \mu \mathrm{g} / \mathrm{mL}$ 의 LPS를 처리한 후 30 분간 재배양한다. Radioimmunoprecipitation assay(RIPA) buffer(50 mM Tris, $150 \mathrm{mM} \mathrm{NaCl}, 2$ mM EDTA, 0.1\% Tween-20, 0.1\% SDS, pH 7.8)에 protease 와 phosphatase inhibitor cocktails(Roche Applied Science, Mannheim, Germany)을 더하여 준비하였다. 배양이 끝난 세 포를 Dulbecco's phosphate buffered saline(DPBS, 1× WelGene Co.)로 3 회 세척하였다. RIPA buffer를 첨가하여 세포 균질액을 얻은 후 원심분리 $\left(13,000 \mathrm{rpm}, 10\right.$ 분, $\left.4^{\circ} \mathrm{C}\right)$ 하여 상층액을 얻었다. 상층액의 단백질 함량은 Bio-Rad protein kit(Hercules, $\mathrm{CA}, \mathrm{USA})$ 을 이용하여 제조사 지침에 따라 측 정하였다. $20 \mu \mathrm{g}$ 단백질을 함유한 상층액을 $12 \%$ sodium 
dodecyl sulfate-polyacrylamide gel electrophoresis(SDSPAGE)로 크기별로 분리한 후, 이 gel을 nitrocellulose blotting membrane(GE Healthcare Life Sciences, Freiburg, Germany)으로 전이시켰다. Antibody의 비특이적 결합을 억 제하기 위해 5\% non-fat dry milk 용액을 각각의 membrane 이 잠길 정도로 부어 1시간 반응을 시킨 후 TBS-T $(20 \mathrm{mM}$ tris- $\mathrm{HCl}, 150 \mathrm{mM} \mathrm{NaCl}, 0.05 \%$ Tween-20, $\mathrm{pH}$ 7.5)로 15 분 씩 3회 세척하였으며, p-Erk(phospho-Erk; Cell Signaling Technology, Danvers MA, USA), Erk(Cell Signaling Technology), p-p38(Cell Signaling Technology), p38(Cell Signaling Technology)과 $\beta$-actin(Cell Signaling Technology) 1 차 항체를 $1: 1,000$ 으로 희석하여 첨가한 후 $4^{\circ} \mathrm{C}$ 에서 18 시간 동안 overnight 하면서 반응시킨 다음 TBS-T로 15 분씩 3 회 세척하였다. 이후 1:2,000으로 희석한 2차 항체(anti-rabbit IgG, HRP-linked antibody; Cell Signaling Technology)를 1 시간 동안 반응시켰다. TBS-T로 15 분마다 3 회 세척 후 2 차 항체와 결합된 단백질은 AbSignal western detection kit (AbClon Inc., Seoul, Korea)으로 처리하였고, 암실에서 Agfa X-ray film(Agfa HealthCare NV, Mortsel, Belgium)으로 밴 드를 시각화하여 스캔하였다. 그 밴드의 강도를 SigmaGel (Jandel Scientific, San Rafael, CA, USA) 소프트웨어에 의해 분석 정량하였고, 단백질 정량은 $\beta$-actin을 참고로 하여 분석 하였다.

\section{ELISA 분석}

Raw264.7 대식세포는 12-well plates에 세포수를 $1 \times 10^{5}$ cells/well로 조정하여 깐 후 24시간 동안 배양하여 2시간 기 아 상태를 유지하였다. Raw264.7 대식세포에 Ast 0, 1, 2.5 그리고 $5 \mu \mathrm{g} / \mathrm{mL}$ 을 2시간 동안 처리한 후 대조군을 제외하고 $0.5 \mu \mathrm{g} / \mathrm{mL}$ 의 LPS를 처리하여 18 시간 재배양한 후 배양 배지 를 얻어 원심분리 $\left(10,000 \mathrm{rpm}, 10\right.$ 분, $\left.4^{\circ} \mathrm{C}\right)$ 하였다. 원심분리 후 상층액에 함유된 TNF- $\alpha$ 과 IL-6 사이토카인 분비량을 ELISA kit(eBioscience Co., San Diego, CA, USA)를 이용하 여 제조사 지침에 따라 측정하였다.

\section{신경세포와 미세아교세포 혼합시스템 구축}

미세아교세포(EOC-20 microglial cells, $1 \times 10^{5}$ cells/cell insert)는 Falcon cell inserts(Cyclopore polyethylene terephthalate 'filters', Pore density: $1.6 \pm 0.6 \times 10^{6} / \mathrm{cm}^{2}$, pore size: $0.1 \mu \mathrm{m}$ )에 분주하였고, 뇌신경세포인 SK-N-SH 세포 $\left(1 \times 10^{5}\right.$ cells/well $)$ 는 12-well culture plate에 분주하였다. Falcon cell inserts는 12-well culture plate에 걸 수 있고 cell inserts의 일정 부분이 12-well culture plate에 잠겨 미세아교세포와 SK-N-SH 세포
가 서로 물질교환이 가능할 수 있는 시스템을 만들었다. 12-well culture plate에 배양하고 있는 SK-N-SH 세포에 Ast 1 그리고 $5 \mu \mathrm{g} / \mathrm{mL}$ 을 처리하였고, 동시에 cell inserts에 배양 중인 미세아교세포는 $1 \mathrm{mM} \mathrm{SNP}$ 를 처리하여 18 시간 배양하 였다. 이때 SK-N-SH 세포를 배양 중인 12-well culture plate 에 첨가한 astragalin이 함유한 배지의 양은 $1 \mathrm{~mL}$ 로 cell inserts가 SK-N-SH 배양 plate에 $1 / 2$ 정도 잠겨 서로 물질교 환이 가능할 수 있는 시스템을 구축하였다.

\section{통계분석}

본 실험 결과들은 평균(mean)士표준편차(standard deviation, $\mathrm{SD}$ )로 표시하였고 실험군 간 평균의 차이는 one-way ANOVA 로 유의성을 확인한 후 Duncan's multiple range test를 이용 하여 사후 검정하였으며 $\mathrm{p}<0.05$ 수준에서 유의성의 여부를 검증하였다. 모든 통계분석은 SPSS(statistical package for the social science) version 17.0 프로그램(SPSS Inc., Chicago, $\mathrm{IL}, \mathrm{USA})$ 을 이용하여 분석하였다.

\section{결과 및 고찰}

\section{참취(Aster scaber)에서 분리된 분획물들의 DPPH 라디칼 소거작용}

참취 에탄올 추출물(EtOH), 에틸아세테이트 분획물(EA), 부탄올 분획물 $(\mathrm{BU})$, 클로로포름 분획물 $(\mathrm{CH})$, 헥산 분획물 $(\mathrm{HX})$ 및 물층 $(\mathrm{AQ})$ 의 $\mathrm{DPPH}$ 라디칼 소거작용을 알아본 결과 실험한 모든 시료 중에 $\mathrm{EA}$ 가 가장 높은 $\mathrm{DPPH}$ 라디칼 소거 작용을 나타내었다(Fig. 1(B)), 항산화 효과가 뛰어난 EA로 부터 astragalin을 Chung 등(2016)과 같은 방법으로 분리 및 분석하였고, 참취 에탄올 추출물을 HPLC로 분석한 결과 astragalin이 함유되어 있다는 것을 알 수 있었고(Fig. 2(B)), 참취 추출물의 EA로부터 얻은 astragalin(Fig. 2(A))을 본 연 구에 사용하였다.

\section{참취(Aster scaber)에서 분리된 astragalin의 Raw264.7 대식세포의 세포 생존율에 미치는 영향}

Raw264.7 대식세포에 $0.5,1,2.5$ 그리고 $5 \mu \mathrm{g} / \mathrm{mL}$ Ast를 처리하여 24시간 동안 배양한 후 세포독성을 알아본 결과는 Fig. 3과 같다. 참취(Aster scaber)에서 분리된 Ast는 모든 농 도에서 세포 생존율이 Ast를 처리하지 않은 대조군(100\%)과 비교하여 유의적 차이가 없었으므로, Ast는 $5 \mu \mathrm{g} / \mathrm{mL}$ 까지 세 포독성이 없다는 것을 알 수 있었다(Fig. 3). 따라서 독성이 나타나지 않는 $5 \mu \mathrm{g} / \mathrm{mL}$ Ast를 최고 농도로 하여 계속되는 실험을 진행하였다. 
(A)

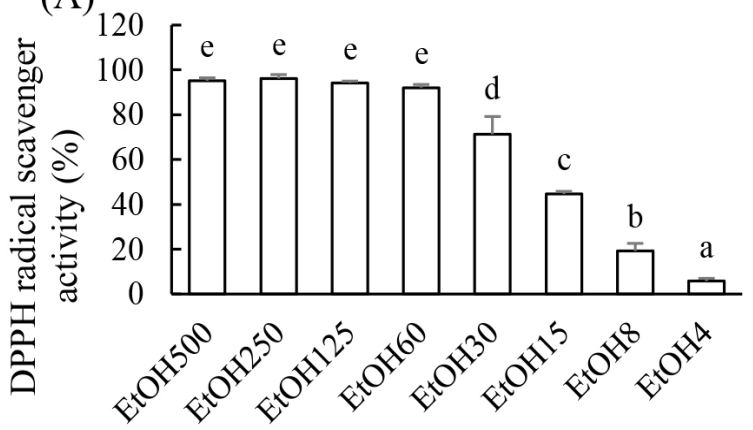

Ethanol $(\mu \mathrm{g} / \mathrm{mL})$

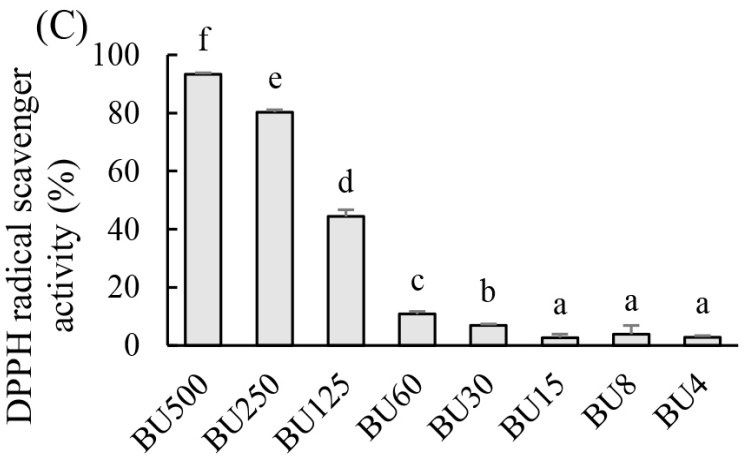

Butanol $(\mu \mathrm{g} / \mathrm{mL})$

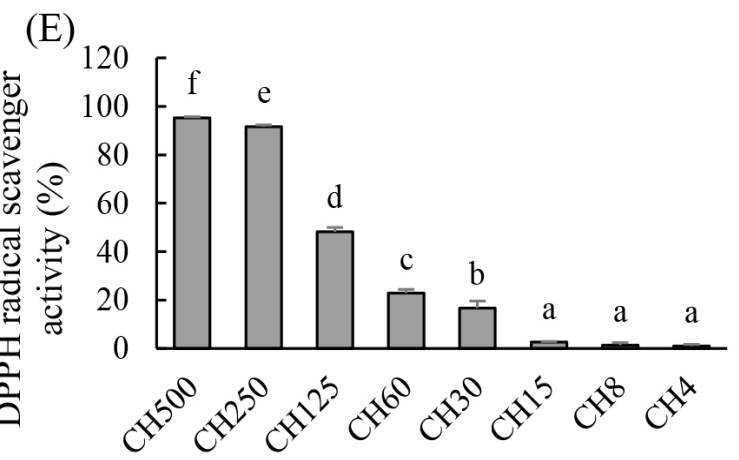

Chloroform $(\mu \mathrm{g} / \mathrm{mL})$

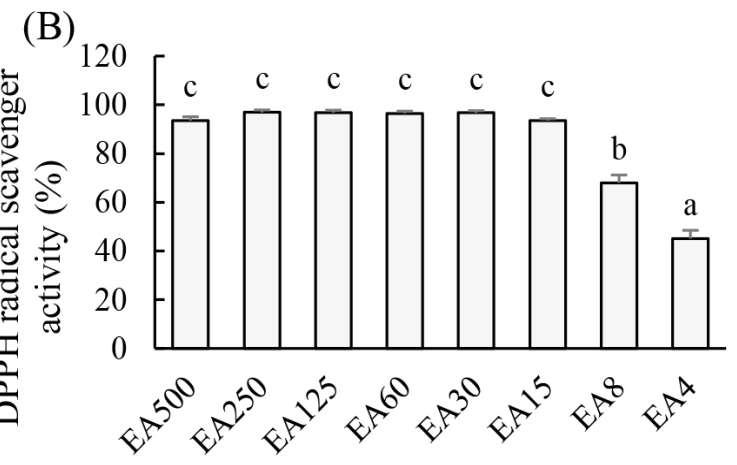

Ethyl acetate $(\mu \mathrm{g} / \mathrm{mL})$

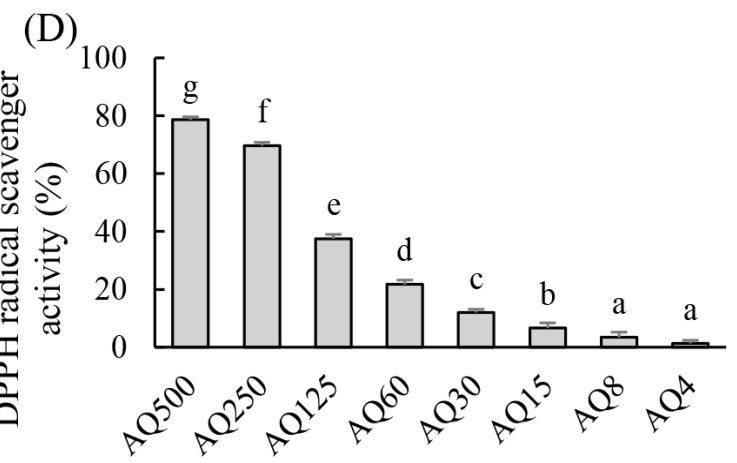

Aqueous layer $(\mu \mathrm{g} / \mathrm{mL})$

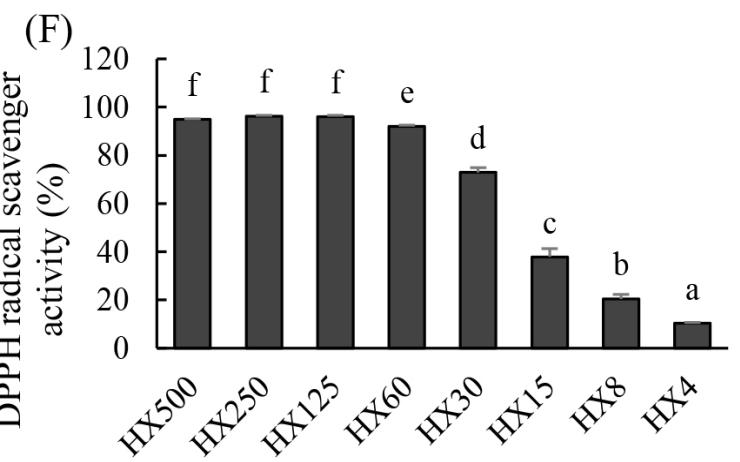

Hexane $(\mu \mathrm{g} / \mathrm{mL})$

Fig. 1. DPPH radical scavenger activity of fractions from Aster scaber.

$\mathrm{EtOH}$ is ethanol extract. The ethyl acetate, butanol, aqueous, chloroform, and hexane fractions from Aster scaber are EA, BU, AQ, CH, and $\mathrm{HX}$, respectively. The values are expressed as the mean $\pm S D(n=4)$, and the means with different letters are significantly different from each other $(p<0.05)$, as determined by Duncan's multiple range test.

참취(Aster scaber)에서 분리된 astragalin가 Raw264.7 대식세포에서 LPS에 의해 유도된 NO 및 cytokines 과분비 에 미치는 영향

내독소의 하나인 LPS를 처리한 후 대식세포에서 과량의 전염증성 사이토카인(TNF- $\alpha, \mathrm{IL}-6, \mathrm{IL}-1 \beta$ 등), $\mathrm{NO}$ 등의 과분
비를 확인함으로써 염증 유발 세포모델이라는 것을 알 수 있 다(Lee과 Lim, 2008).

본 연구에서는 astragalin의 항염증 효과를 알아보기 위해 Raw264.7 대식세포에 Ast를 먼저 처리한 후 LPS를 처리하 였다. Ast $0.5,1,2.5$ 그리고 $5 \mu \mathrm{g} / \mathrm{mL}$ 를 처리한 결과 LPS에 
(A)<smiles>O=c1c(OC2C(O)C(CO)OC(CO)C(O)C2O)c(-c2ccc(O)cc2)oc2cc(O)cc(O)c12</smiles>

(B)

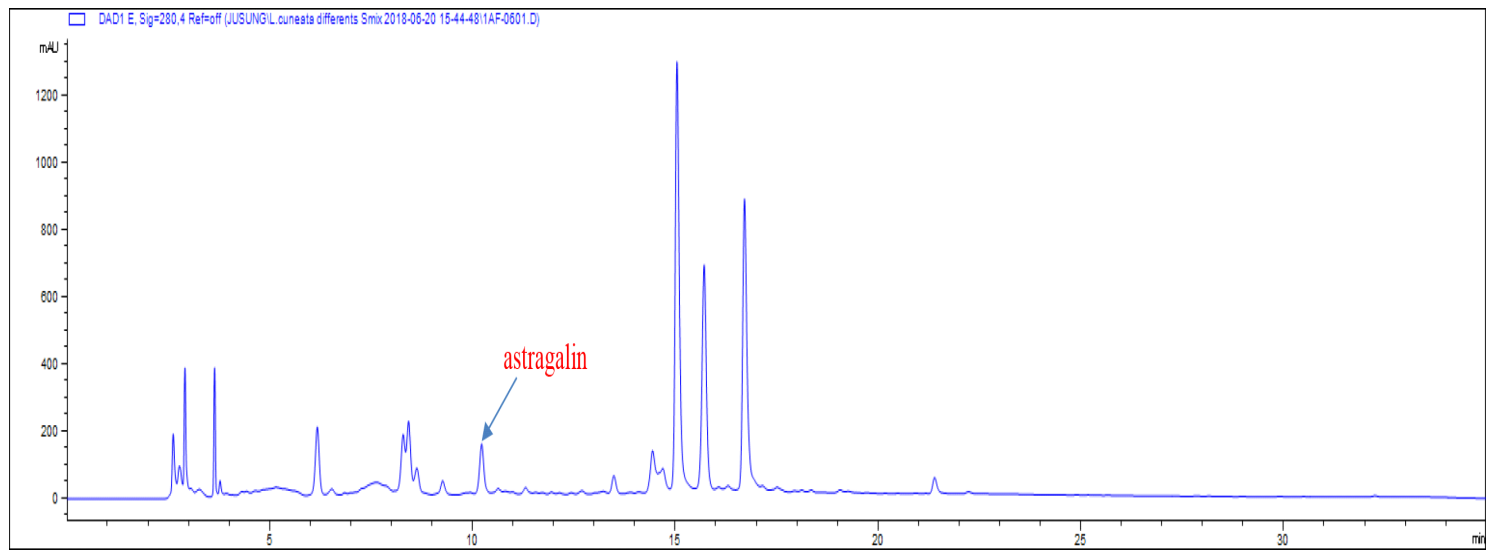

Fig. 2. Chemical structure of astragalin.

The astragalin was isolated from Aster scaber and identified by method of Chung et al. (2016) (A) and HPLC chromatograms of the EtOH extract of Aster scaber (B).

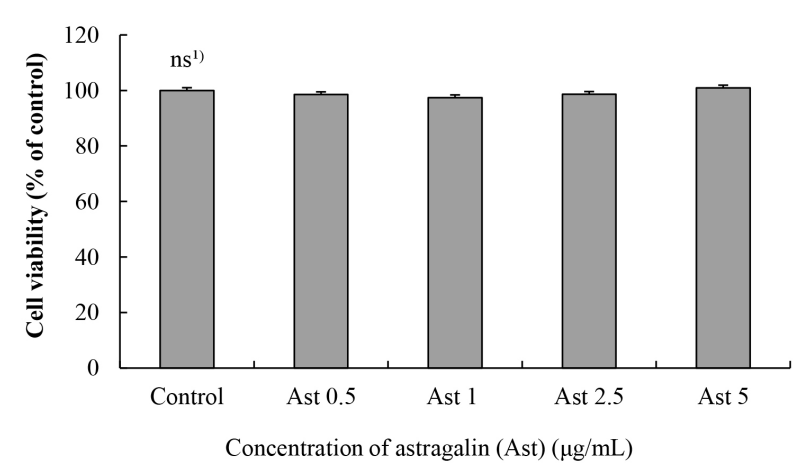

Fig. 3. Effects of astragalin isolated from Aster scaber on cell viability in Raw264.7 macrophage cells.

The cells were treated with the various concentration $(0.25,0.5,1$ and $2.5 \mu \mathrm{g} / \mathrm{mL}$ ) of astragalin (Ast) for $24 \mathrm{~h}$. The values are expressed as the mean \pm SD $(n=4)$.

${ }^{1)}$ ns, not significant.

의해 과분비 된 $\mathrm{NO}$ 가 농도 의존적으로 감소하였다(Fig. 4(A)). Ast를 처리한 후 LPS를 처리하였고, 18시간 후 배지 에 TNF- $\alpha$ 와 IL-6 분비량을 측정한 결과 LPS에 의해 과분비
된 TNF- $\alpha$ 와 IL- 6 분비량 농도 의존적으로 감소하였다(Fig. 4(B), 4(C)).

마우스 복강대식세포에서 상엽 유래 astragaline을 처리한 2시간 후에 LPS $(1 \mu \mathrm{g} / \mathrm{mL})$ 로 자극하여 24시간 배양한 다음 세포 상층액을 분리하여 NO, PGE2 와 IL-6를 측정한 결과 astragalin 처리로 이들 물질이 유의적으로 감소하였다고 하 였는데 본 연구 결과와 유사하였다(Mok 등, 2011). 마우스에 astragaline을 구강 투여 후 LPS를 처리했을 때 폐에서 LPS 에 의해 유도된 NF-kB/MAPK 활성을 억제함으로써 TNF- $\alpha$, $\mathrm{IL}-1 \beta$ 그리고 $\mathrm{IL}-6$ 의 함량을 감소시켰다 $(\mathrm{Li}$ 등, 2017 ; Soramou 등, 2012). 따라서 본 연구에서는 참취에서 분리된 astragalin이 대식세포에서 어떤 기전에 의해 NO 및 cytokines 생성을 억제하는지 알아보았다.

\section{참취(Aster scaber)에서 분리된 astragalin가 Raw264.7 대식세포에서 LPS에 의해 유도된 Erk와 p-38 신호전달경 로 활성화에 미치는 영향}

대식세포 내 Erk, JNK 및 p38을 포함한 MAPKs 신호 경 
(A)

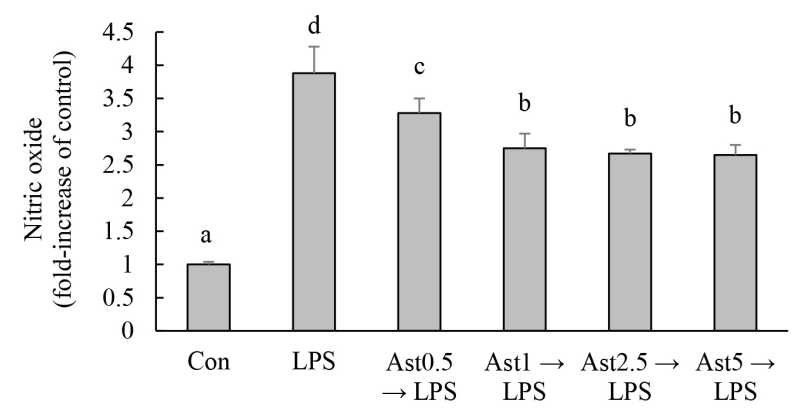

(B)

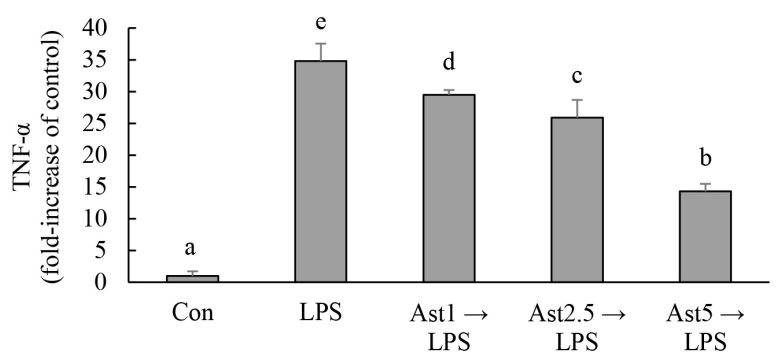

(C)

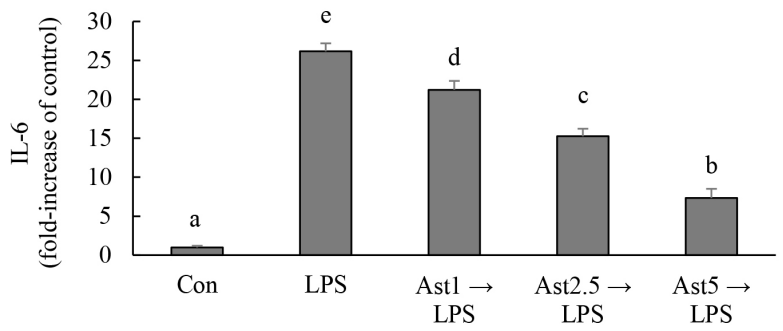

Fig. 4. Effects of astragalin isolated from Aster scaber on nitric oxide (A), TNF- $\alpha$ (B) and IL-6 (C) levels in LPS-stimulated Raw264.7 macrophage cells.

The cells were pretreated with astragalin (Ast) $(1,2.5$, and $5 \mu \mathrm{g} / \mathrm{mL})$ for $2 \mathrm{~h}$, followed by treatment with the LPS $(0.5 \mu \mathrm{g} / \mathrm{mL})$ for $18 \mathrm{~h}$. The nitrite content of culture media was anlyzed. Control and LPS were control cells (Ast and LPS-untreated cells) and LPS group cells (cell treated with LPS only). The values are expressed as the mean $\pm \mathrm{SD}(\mathrm{n}=4)$, and the means with different letters are significantly different from each other.

로는 염증성 시스템의 중요한 신호전달 반응을 매개하고 (Erwig과 Henson, 2007; Medzhitov과 Janeway, 1998), 항염 증 효과를 가진 천연소재들은 NF-kB/MAPK 신호 전달경로 를 억제함으로써 LPS에 의해 활성화된 Raw264.7 세포에서 염증성 사이토카인 분비를 억제하는 것으로 알려져 있다 $(\mathrm{Li}$ 등, 2017).

참취에서 분리한 astragalin $0,0.5,1,2.5$ 그리고 $5 \mu \mathrm{g} / \mathrm{mL}$ 를 2 시간 처리 후 LPS를 30 분 처리한 결과 LPS 처리한 Raw264.7 대식세포 내 Erk와 p38의 인산화(p-Erk와 p-p38)
가 무처리군인 대조군과 비교하여 3.4배와 2.4배 증가하였고, Ast 처리에 의해 증가한 p-Erk와 p-p38 단백질 함량이 유의 적으로 감소하였다(Fig. 5).

Raw264.7 대식세포에서 LPS에 의해 증가한 MAPKs(Erk, $\mathrm{JNK}$ 그리고 $\mathrm{p}-38$ )의 신호 전달 경로는 헛개나무 추출물, stevioside 그리고 7,8-dihydroxyflavone에 의해 억제되었다 (Fengyang 등, 2012; Park 등, 2012; Woo 등, 2018). Raw264.7 대식세포에서 Koumine과 isoquercitrin은 LPS 처리로 활성 화된 ERK와 p38 신호전달경로 억제를 통해 항염증 효과를 나타낸다고 하였는데(Lee 등, 2019; Yuan 등, 2016), 본 연구 에서도 astragalin에 의해 억제된 Erk와 p38의 신호 경로에 의해 염증성 사이토카인 분비가 감소되어 항염증 효과를 나 타낼 수 있을 것으로 예측된다.

\section{미세아교세포 및 뇌신경세포 혼합배양 시스템에서 과다 생성된 NO에 대항하여 참취(Aster scaber)에서 분리된 astragalin의 뇌신경세포 보호 효과}

본 연구에서는 계속하여 대식세포의 항염증 효과를 가진 astragalin이 해마에 신경세포와 함께 분포된 활성화된 미세 아교세포에서 과량으로 분비되는 $\mathrm{NO}$ 를 감소시켜 뇌신경세 포 보호 효과를 가지고 있는지 알아보는 실험을 진행하였다. $\mathrm{SNP}$ 는 세포내에서 $\mathrm{NO}$ 를 과량 생성할 수 있는 $\mathrm{NO}$ donor로 사용하였다.

인간 신경모세포종 SK-N-SH 세포에 $0.025,0.05,0.1$, $0.25,0.5,1,2,4$ 그리고 $8 \mathrm{mM} \mathrm{SNP}$ 를 18 시간 처리한 결과, $0.5 \mathrm{mM} \mathrm{SNP}$ 처리군에서는 대조군과 비교하여 유의적 차이 가 없었고 $1 \mathrm{mM} \mathrm{SNP}$ 처리에 의해 대조군(생존율 $100 \%$ )과 비교하여 생존율이 $82.4 \%$ 로 유의적으로 SK-N-SH 세포가 사멸하였다(Fig. 6(A)). Ast 0.5, 1, 2.5 그리고 $5 \mu \mathrm{g} / \mathrm{mL}$ 를 2시 간 동안 처리한 후 $1 \mathrm{mM} \mathrm{SNP}$ 를 18 시간 처리한 결과, 농도 의존적으로 SN-N-SH 세포 생존율이 증가하여 Ast 2.5 그리 고 $5 \mu \mathrm{g} / \mathrm{mL}$ 처리군은 LPS를 처리하지 않은 대조군 수준으로 회복하였다(Fig. 6(B)). 미세아교세포(EOC20)에 $1 \mathrm{mM} \mathrm{SNP}$ 를 $18 \mathrm{~h}$ 처리한 결과, 세포 생존율은 $90 \%$ 이고, $\mathrm{NO}$ 는 무처리 군인 대조군과 비교하여 약 18 배 증가하였다(data not shown).

알츠하이머 질환(Alzheimer's disease)은 뇌 내 amyloid $\beta$ (AB) 펩타이드가 비정상적으로 다량 만들어져 뇌 조직에 senile plaque가 형성되면 microglia가 이를 항원으로 인식하 여 활성화되고 염증을 일으키는 proinflammatory cytokines 및 $\mathrm{NO}$ 를 과량 방출하여 염증 반응을 유발한다(Selkoe, 2001). 미세아교세포와 뇌신경세포가 공존하고 있는 뇌 해마에서 활 성화된 미세아교세포는 과량의 $\mathrm{NO}$, proinflammatory cytokines 를 분비하여 뇌신경세포가 손상되어 알츠하이머 질환, 파킨 슨 질환(Parkinson's disease) 등과 같은 퇴행성 신경 질환이 
(A)

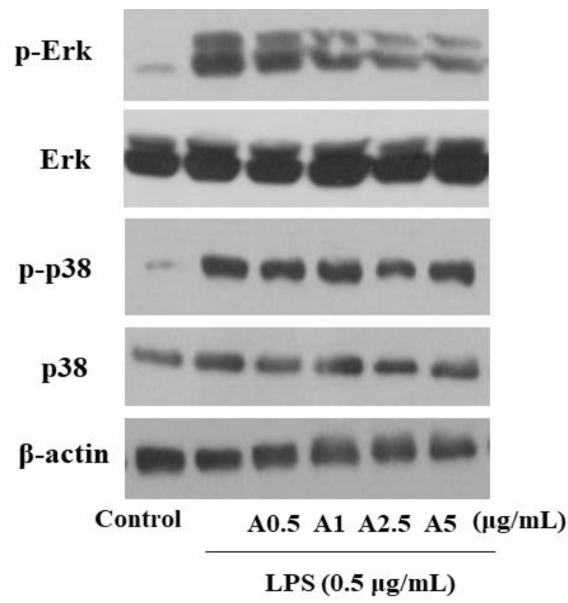

(B)

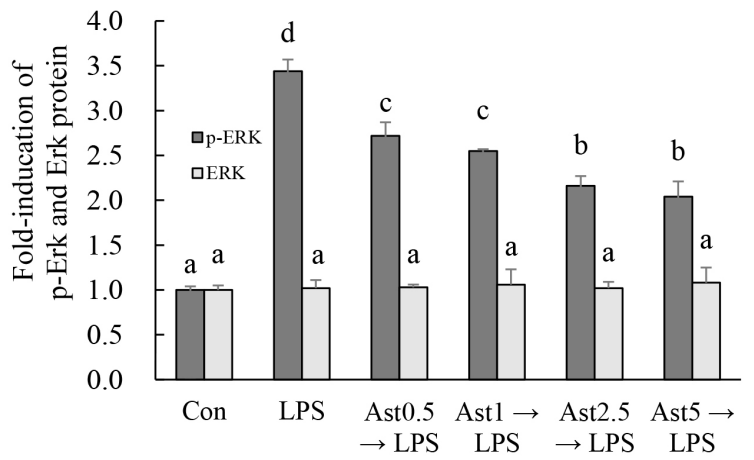

(C)

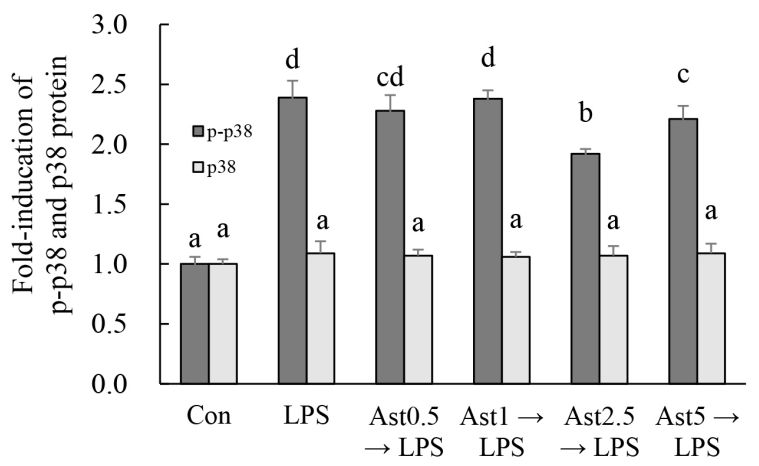

Fig. 5. Effects of astragalin isolated from Aster scaber on LPSinduced phosphorylation of Erk and p38 in Raw264.7 macrophage cells.

The cells were pretreated with astragalin $(0.5,1,2.5$, and $5 \mu \mathrm{g} / \mathrm{mL})$ for $2 \mathrm{~h}$, followed by treatment with the LPS $(0.5 \mu \mathrm{g} / \mathrm{mL})$ for $30 \mathrm{~min}$. $\mathrm{A}$ and Ast are astragalin. The Erk, p-Erk, p38, and p-p38 levels in each sample were normalized to the $\beta$-actin levels. The density of each protein band was quantified by using SigmaGel software. Control and LPS were control cells (LPS and Ast-untreated cells) and LPS group cells (cell treated with the LPS only), respectively. The phosphorylation of Erk and p38 was abbreviated by p-Erk and p-p38. The values are expressed as the mean \pm SD $(n=3)$, and the means with different letters are significantly different from each other $(p<0.05)$, as determined by Duncan's multiple range test.
(A)

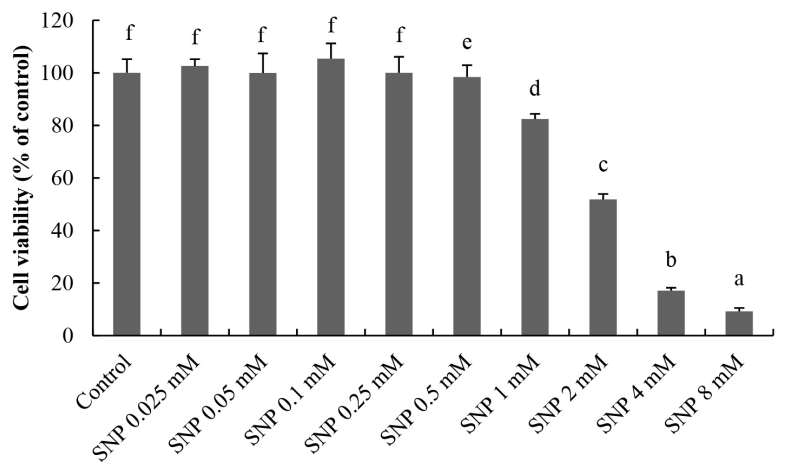

(B)

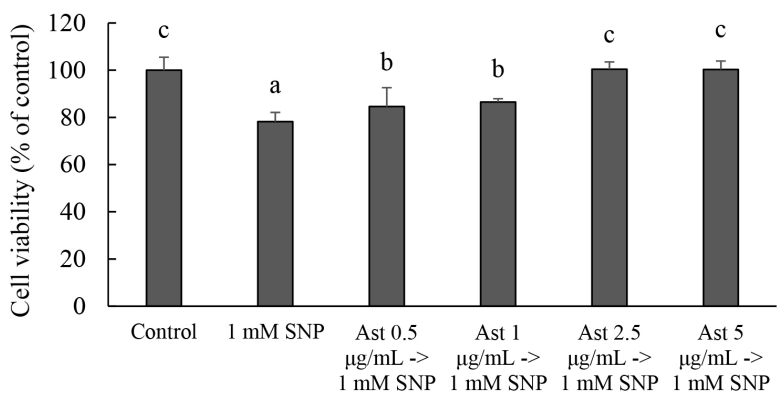

Fig. 6. SNP-induced cytotoxicity (A) and effect of astragalin isolated from Aster scaber on SNP-induced cytotoxicity of SK-N-SH cells (B).

(A) The cells were treated with various concentrations $(0.025,0.05$, $0.1,0.25,1,2,4$, and $8 \mathrm{mM}$ ) of sodium nitroprusside (SNP) for 18 h. (B) The cells were pretreated with astragalin (Ast) for $2 \mathrm{~h}$, followed by treatment with the SNP $(1 \mathrm{mM})$ for $18 \mathrm{~h}$. The values are expressed as the mean $\pm \mathrm{SD} \quad(\mathrm{n}=4)$, and the means with different letters are significantly different from each other $(p<0.05)$, as determined by Duncan's multiple range test.

유발될 수 있다(Chung 등, 2016; Lee 등, 2018; Lee 등, 2019; Meda 등, 1995). 본 연구에서는 미세아교세포와 뇌신 경세포가 공존해 있는 해마와 같은 유사한 시스템을 구축하 기 위해 미세아교세포(EOC-20 microglia)는 cell inserts에 배 양하였고, 뇌신경세포(SK-N-SH 세포)는 cell inserts를 걸 수 있도록 제작된 12-well culture plate에 배양하였다.

활성화된 미세아교세포(microglia)는 TNF- $\alpha$, IL-6 그리고 $\mathrm{NO}$ 를 과량 분비하여 염증을 유발하고, 뇌의 해마에 존재하 는 미세아교세포 활성화에 의한 cytokines와 $\mathrm{NO}$ 의 과량 분 비는 뇌염증을 유발할 수 있으며, 이들 물질을 억제하는 항염 증 효과 및 뇌염증 효과에 의한 뇌질환 예방 및 개선 천연소 재 발굴이 가능할 것이다(Yang 등, 2020).

$\mathrm{SNP}$ 는 NO donor로 이것을 처리하면 미세아교세포가 염 증반응에 의해 $\mathrm{NO}$ 가 증가한 것과 같은 과량의 $\mathrm{NO}$ 가 생성된 염증세포 모델이 될 수 있다(Lee 등, 2019). Cell inserts는 물 
질교환이 가능한 막으로 구성되어 있으며 1/2정도 12-well culture plate에 잠겨 있으므로 SNP 처리에 의한 미세아교세 포로부터 과분비 되는 NO가 cell inserts 막을 통해 아래에 배양 중인 SK-N-SH 세포 사멸에 영향을 줄 수 있도록 혼합 배양 시스템을 구축하였다.

미세아교세포에 대조군을 제외하고 모든 군에 $1 \mathrm{mM} \mathrm{SNP}$ 를 처리할 때 SK-N-SH 세포 내 $\mathrm{NO}$ 의 함량은 대조군보다 현저하게 증가하였고, SK-N-SH에 Ast 처리로 이들 증가는 유의적으로 감소하였다(Fig. 7(A)). SK-N-SH 세포의 세포 생존율은 미세아교세포에 처리한 SNP 처리 때문에 유의적으 로 감소하였으나 SK-N-SH 세포에 Ast를 처리했을 때 세포 생존율이 유의적으로 증가하였다(Fig. 7(B)).

따라서 본 연구 결과는 해마에서 미세아교세포가 활성화 되어 과량의 $\mathrm{NO}$ 를 분비하여도 $\mathrm{Ast}$ 에 의해 뇌신경세포 사멸 이 억제될 수 있을 것이라는 것을 추측할 수 있지만 Ast가

(A)

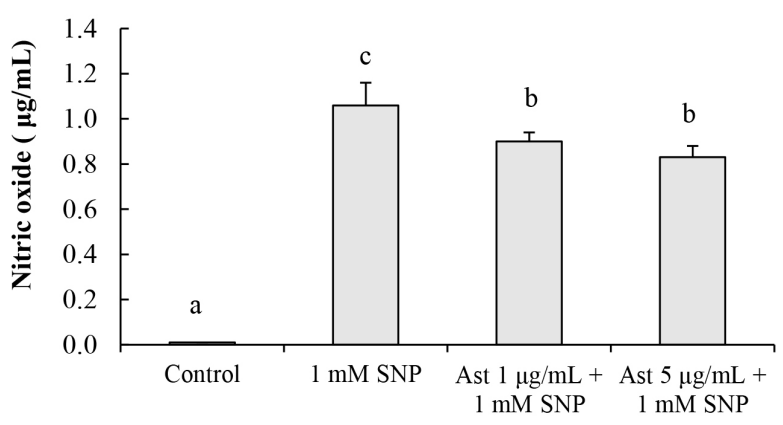

(B)

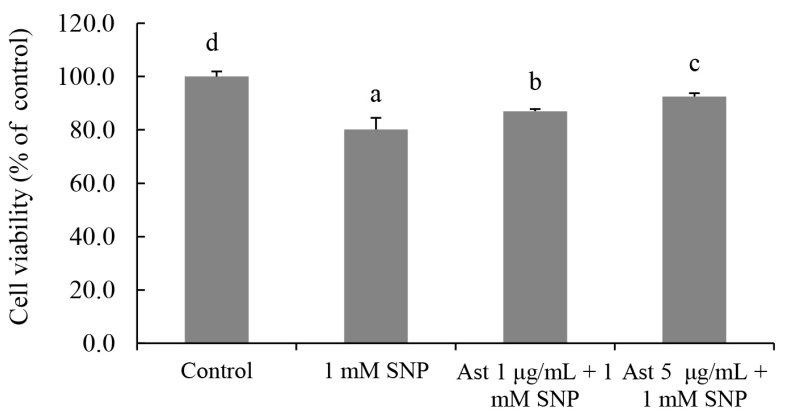

Fig. 7. Effects of astragalin isolated from Aster scaber on NO level (A) and cell death (B) in SNP-treated SK-N-SH cells.

The SK-N-SH cells in 12-well culture plate were treated with astragalin (Ast) and the microglia on cell insert was treated with sodium nitroprusside (SNP) $(1 \mathrm{mM})$ for $18 \mathrm{~h}$. The nitrite content of culture media in SK-N-SH cells was analyzed. Control and SNP were control cells (Ast and SNP-untreated cells) and SNP group cells (cell treated with SNP only), respectively. The values are expressed as the mean \pm SD $(n=4)$, and the means with different letters are significantly different from each other $(\mathrm{p}<0.05)$, as determined by Duncan's multiple range test.
해마까지 물질 전달이 가능한지에 관한 연구들이 필요할 것 으로 생각된다.

\section{요 약}

본 연구의 목적은 LPS로 자극된 Raw264.7 대식세포에서 Aster scaber에서 분리된 astragalin(Ast)의 항염 효과와 nitric oxide 유도 신경 세포 사멸에 대한 Ast의 신경 보호 효과를 연구하는 것이다. Aster scaber의 에틸아세테이트 분획물은 에탄올 추출물과 5 개 분획물 중 가장 높은 $\mathrm{DPPH}$ 라디칼 소 거 활성을 나타냈다. Aster scaber의 에틸아세테이트 분획물 에서 분리된 Ast를 세포에 전처리 후 LPS를 처리하여 적절 한 시간 동안 추가 배양하였다. Ast는 LPS에 의해 활성화된 Raw264.7 세포에서 NO, TNF- $\alpha$ 및 IL-6의 농도를 감소시켰 다. 이러한 억제 효과는 Ast에 의한 MAPKs 경로의 활성화가 억제됨으로써 발생하였다. SNP는 NO 공여체로 사용되었다. Ast는 NO의 과잉 생산에 의한 세포독성에 대항하여 SK-N$\mathrm{SH}$ 세포의 생존 수준을 증가시켰다. Ast의 효과는 혼합 배양 된 세포(SK-N-SH 세포 및 미세아교세포)에서 나타났다. Ast 는 SK-N-SH 세포에 처리하고 미세아교세포는 SNP 처리한 조건에서 Ast는 과량 생성된 NO로부터 SK-N- SH 세포에 대한 보호 효과가 나타났다. 이러한 결과는 Ast가 Ast의 항염 효과에 의해 뇌신경세포 보호제로 활용 가능성이 있다는 것 을 시사하고 있다.

\section{감사의 글}

이 논문은 2016년도 정부(미래창조과학부)의 재원으로 한 국연구재단의 지원을 받아 수행된 연구임(No. NRF-2016R1 A2B1014829).

\section{Conflict of interests}

The authors declare no potential conflict of interest.

\section{ORCID}

Eun-Hae Kim https://orcid.org/0000-0002-7390-089X

Mi Ja Chung https://orcid.org/0000-0003-0816-1354

\section{References}

Choi HJ, Kim SH, Oh HT, Chung MJ, Cui CB, Ham SS. Effects of Adenophora triphylla ethylacetate extract on 
mRNA levels of antioxidant enzymes in human HepG2 cells. J Korean Soc Food Sci Nutr, 37, 1238-1243 (2008)

Chung MJ, Lee SH, Park YI, Lee JS, Kwon KH. Neuroprotective effects of phytosterols and flavonoids from Cirsium setidens and Aster scaber in human brain neuroblastoma SK-N-SH cells. Life Sci, 148, 173-182 (2016)

Erwig LP, Henson PM. Immunological consequences of apoptotic cell phagocytosis. Am J Pathol, 171, 2-8 (2007)

Fengyang L, Yunhe F, Bo L, Zhicheng L, Depeng L, Dejie L, Wen Z, Yongguo G, Naisheng Z, Xichen Z, Zhengtao Y. Stevioside suppressed inflammatory cytokine secretion by downregulation of NF-kB and MAPK signaling pathways in LPS-stimulated RAW264.7 cells. Inflammation, 35, 1669-1675 (2012)

Kim SJ, Lee SH, Park SE, Lee JS, Chung MJ. Neuroprotective effects of bread containing Aster scaber Thunb. and Stachys sieboldii Miq. against ethanol- or $\mathrm{H}_{2} \mathrm{O}_{2}$-induced neuronal cell death. J Korean Soc Food Sci Nutr, 47, 24-31 (2018)

Kreutzberg GW. Microglia: A sensor for pathological events in the CNS. Trends Neurosci, 19, 312-318 (1996)

Lee HI, Gwak JY, Chung MJ. Inhibitory effects of Platycodon grandiflorum, Codonopsis lanceolata, corn silk, and Acanthopanax senticosus against nitric oxide-induced cytotoxicity in SK-N-SH cells. 48, 823-832 (2019)

Lee HI, Kim EH, Lee SH, Chung MJ. Anti-inflammatory and neuroprotective efffects of isoquercitrin isolated from Aster scaber. J Korean Soc Food Sci Nutr, 48, 1205-1213 (2019)

Lee SJ, Lim KT. Phytoglycoprotein inhibits interleukin-1 $\beta$ and interleukin-6 via p38 mitogen activated protein kinase in lipopolysaccharide stimulated RAW264.7 cells. Naunyn-Schmied Arch Pharmacol, 377, 45-54 (2008)

Li Y, He S, Tang J, Ding N, Chu X, Cheng L, Ding X, Liang $\mathrm{T}$, Feng $\mathrm{S}$, Rahman SU, Wang $\mathrm{X}$, Wu J. Andrographolide inhibits inflammatory cytokines secretion in LPS-stimulated RAW264.7 cells through suppression of NF-kB/MAPK signaling pathway. J Evid Based Complementary Altern Med, 2017, 8248142 (2017)

McCord JM. Free radicals and inflammation: Protection of synovial fluid by superoxide dismutase. Science, 185, 529-531 (1974)
McGeer PL, McGeer EG. Inflammation and the degenerative diseases of aging. Ann N Y Acad Sci, 1035, 104-116 (2004)

Meda L, Cassatella MA, Szendrei GI, Otvos LJr, Baron P, Villalba M, Ferrari D, Rossi F. Activation of microglial cells by beta-amyloid protein and interferon-gamma. Nature, 374, 647-650 (1995)

Medzhitov R, Janeway CA Jr. An ancient system of host defense. Curr Opin Immunol, 10, 12-15 (1998)

Mok JY, Jeong SI, Kim JH, Jang SI. Synergic effect of quercetin and astragalin from mulberry leaves on antiinflammation. Korean J Oriental Physiology \& Pathology, 25, 830-836 (2011)

Park HY, Kim GY, Hyun JW, Hwang HJ, Kim ND, Kim BW, Choi YH. 7,8-Dihydroxyflavone exhibits antiinflammatory properties by downregulating the NF-kB and MAPK signaling pathways in lipopolysaccharidetreated Raw264.7 cells. Int J Mol Med, 29, 1146-1152 (2012)

Ryu JH, Ahn H, Kim JY, Kim YK. Inhibitory activity of plant extracts on nitric oxide synthesis in LPS-activated macrophage. Phytother Res, 17, 485-489 (2003)

Selkoe DJ. Alzheimer's disease: Genes, proteins, and therapy. Physiol Rev, 81, 741-766 (2001)

Soromou LW, Chen N, Jiang L, Huo M, Wei M, Chu X, Millimouno FM, Feng H, Sidime Y, Deng X. Astragalin attenuates lipopolysaccharide-induced inflammatory responses by down-regulating NF-kB signaling pathway. Biochem Biophys Res Commun, 419, 256-261 (2012)

Woo HS, Lee SM, Heo JD, Lee MS, Kim YS, Kim DW. Anti-inflammatory activity of extracts of Hovenia dulcis on lipopolysaccharides-stimulated Raw264.7 cells. Korean J Plant Res, 31, 466-477 (2018)

Yang S, Chu S, Ai Q, Zhang Z, Gao Y, Lin M, Liu Y, Hu Y, Li X, Peng Y, Pan Y, He Q, Chen N. Antiinflammatory effects of higenamine (Hig) on LPSactivated mouse microglia (BV2) through NF-kB and Nrf2/OH-1 signaling pathways. Int Immunopharmacol, 85, 106629 (2020)

Yuan Z, Matias FB, Wu J, Liang Z, Sun Z. Koumine attenuates lipopolysaccaride-stimulated inflammation in Raw264.7 macrophages, coincidentally associated with inhibition of NF-kB, ERK and p38 pathways. Int J Mol Sci, 17, 1-11 (2016) 